\title{
Detection of Clostridium difficile toxin A/B genes by multiplex real-time PCR for the diagnosis of C. difficile infection
}

Correspondence

Seok Hoon Jeong

kscpjsh@yuhs.ac

Received 26 June 2011

Accepted 25 September 2011

\author{
Heejung Kim, Seok Hoon Jeong, Myungsook Kim, Yangsoon Lee \\ and Kyungwon Lee
}

Department of Laboratory Medicine and Research Institute of Bacterial Resistance, Yonsei University College of Medicine, 50 Yonsei-ro, Seodaemun-gu, Seoul 120-752, Republic of Korea

\begin{abstract}
Toxigenic Clostridium difficile culture is considered to be the standard diagnostic method for the detection of C. difficile infection (CDI). Culture methods are time-consuming and although enzyme immunoassay is rapid and easy to use, it has low sensitivity. In the present study, the AdvanSure CD real-time (RT)-PCR kit (LG Life Sciences) was evaluated for its ability to detect $C$. difficile toxin $\mathrm{A}(t c d A)$ and $\mathrm{B}(t c d B)$ genes, simultaneously. A total of 127 fresh diarrhoeal stool specimens, submitted to the clinical microbiology laboratory for $C$. difficile culture, were tested. C. difficile toxins and toxin genes were detected with a VIDAS C. difficile A\&B (VIDAS-CDAB) enzyme-linked fluorescent immunoassay (ELFA) and the AdvanSure RT-PCR kit, respectively, according to the manufacturers' instructions. Their performance was compared with a standard toxigenic culture method as a reference. The sensitivity, specificity and positive and negative predictive values using the AdvanSure RT-PCR kit were $100 \%, 98.3 \%, 84.6 \%$ and $100 \%$, respectively, while those of the VIDAS-CDAB system were $63.6 \%, 100 \%, 100 \%$ and $96.6 \%$, respectively. Four $t c d A^{+} / t c d B^{+}$strains of $C$. difficile were detected with the AdvanSure RT-PCR kit, which offers comparable sensitivity and specificity to the reference method with a turnaround time of $\sim 3$ hours.
\end{abstract}

\section{INTRODUCTION}

Clostridium difficile usually produces two toxins, toxin A (TcdA, an enterotoxin) and toxin B (TcdB, a cytotoxin), and is responsible for a range of diseases from mild diarrhoea to pseudomembranous colitis. This micro-organism is the most common cause of healthcare-associated diarrhoea (Bartlett, 2002). In recent years, the incidence of $C$. difficile infection (CDI) has rapidly increased as has disease severity associated with the emergence of hypervirulent strain BI/ NAP1/027 (McDonald et al., 2005; Kuijper et al., 2008).

The gold standards for CDI diagnosis, currently in use, are the cytotoxicity assay and toxigenic culture method. Twostep testing, in which a negative result with one test is considered to be negative but a positive result is subjected to further testing, has also been proposed to combine the benefits of greater sensitivity, rapid turn-around time and reduced cost (Crobach et al., 2009; Cohen et al., 2010). C. difficile culture has the demerit of being time-consuming, taking up to $72 \mathrm{~h}$ to produce results. Although various enzyme immunoassays (EIA) have proven to have sensitivities that are less than optimal as diagnostic tests, they

Abbreviations: CDI, Clostridium difficile infection; EIA, enzyme-linked immunoassay; ELFA, enzyme-linked fluorescent immunoassay; RT, realtime. are the assays that are most commonly used due to their rapidity and ease of use (Ticehurst et al., 2006; Eastwood et al., 2009). Thus, a single, rapid and accurate diagnostic test is needed.

Real-time (RT)-PCR for the detection of the $t c d B$ gene and multiplex RT-PCRs for the detection of $t c d B$ gene deletions and $t c d C$ gene mutations at nucleotide 117 have been developed, especially for the presumptive identification of epidemic strain BI/NAP/027. (Eastwood et al., 2009; Huang et al., 2009; de Boer et al., 2010; Barbut et al., 2011; Knetsch et al. 2011). The sensitivities and specificities of these tests have been reported to be $88.5-100 \%$ and 88.0 $97.7 \%$, respectively. Recently, a new RT-PCR kit, the AdvanSure CD RT-PCR kit (LG Life Sciences) was developed. The kit can simultaneously detect $t c d A$ and $t c d B$ genes and easily recognize $t c d A^{-} / t c d B^{+}$strains of $C$. difficile. To our knowledge, this is the first study to evaluate the AdvanSure multiplex RT-PCR kit for diagnosing CDI.

\section{METHODS}

Stool specimens. A total of 127 fresh diarrhoeal stool specimens, submitted to the clinical microbiology laboratory of the Severance Hospital for C. difficile culture from June to July 2010, were analysed. The specimens were obtained consecutively and with no duplicates. 
Toxigenic culture (anaerobic culture followed by detection of $t c d A$ and $t c d B$ genes by PCR), VIDAS $C$. difficile Toxin A\&B (VIDASCDAB; bioMérieux) ELFA and AdvanSure RT-PCR methods were performed on the day of specimen reception by independent laboratory staff. Assay performance (sensitivity, specificity and positive and negative predictive values) of the AdvanSure RT-PCR and the VIDAS-CDAB kits were estimated and compared, using the results of the toxigenic culture as a reference method.

Toxigenic C. difficile culture and detection of toxins. Stool specimens were cultured anaerobically on $C$. difficile selective agar (CDSA; Becton Dickinson) for $48 \mathrm{~h}$ at $37{ }^{\circ} \mathrm{C}$. Species identification was performed on the basis of typical colony morphology on agar plates as well as characteristic odour and ATB 32A system (bioMérieux) results. PCR experiments were performed to detect $C$. difficile toxin genes as described in previous studies (Spigaglia \& Mastrantonio, 2004; Terhes et al., 2004). The primer pairs used were NK9-NK11 for the repetitive domain of the $t c d A$ gene, NK104-NK105 for the $t c d B$ gene, cdtA pos-cdtA rev for the $c d t A$ gene and $c d t B$ poscdtB rev for the $c d t B$ gene. C. difficile strains VPI $10463\left(t c d A^{+} /\right.$ $\left.t c d B^{+} / c d t^{-}\right), 3608 / 03\left(t c d A^{-} / t c d B^{-} / c d t^{-}\right), \quad$ SE844 $\left(t c d A^{+} / t c d B^{+} /\right.$ $\left.c d t^{+}\right)$and $1470\left(t c d A^{-} / t c d B^{+} / c d t^{-}\right)$were used as controls for the PCR assays. Stool specimens were examined for toxins with the VIDAS-CDAB kit using mini-VIDAS (bioMérieux) according to the manufacturer's instructions.

Detection of toxin genes by commercial multiplex RT-PCR. Stool specimens were subjected to nucleic acid extraction using the QIAamp DNA stool minikit and a QIAcube (Qiagen), according to the manufacturer's instructions. The AdvanSure RT-PCR kit (LG Life Science) was used for the simultaneous detection of $t c d A$ and $t c d B$ genes. The primers targeted repeated sequences of the $t c d A$ gene and non-repeated sequences of the $t c d B$ gene based on TaqMan technology. RT-PCR experiments were performed on a SLAN RTPCR detection system (LG Life Science) according to the manufacturer's instructions. Results were automatically interpreted using a cut-off value of 0.1. A threshold cycle (Ct) less than 38 was considered positive. Invalid results, which were defined as a negative signal with the internal control for PCR, were retested. To determine the detection sensitivity of the AdvanSure RT-PCR assay, ten-fold serial dilutions of $C$. difficile strains VPI10463 $\left(t c d A^{+} / t c d B^{+}\right)$and 1470 $\left(t c d A^{-} / t c d B^{+}\right)$were used along with genomic DNA of $C$. difficile ATCC $9689 \mathrm{D}$ from $50 \mathrm{ng}$ to $5 \times 10^{-10} \mathrm{ng}$. To evaluate the specificity of the AdvanSure RT-PCR assay, DNA of clinical isolates of Clostridium tertium, Clostridium septicum, Clostridium clostridiiforme and Clostridium perfringens were used.

\section{RESULTS AND DISCUSSIONS}

The analytical sensitivity for AdvanSure RT-PCR was 1 c.f.u. for $t c d B$ detection and 10 c.f.u. for $t c d A$ detection per reaction (data not shown). The limits of detection of $t c d A$ and $t c d B$ genes were $5 \times 10^{-5} \mathrm{ng}$ and $5 \times 10^{-6} \mathrm{ng}$ genomic DNA, respectively. This was comparable to the detection limits of $1-10$ c.f.u. per reaction using the $\mathrm{BD}$ GeneOhm Cdiff PCR assay reported by Stamper et al. (2009) and $<10$ pg of genomic DNA reported by Barbut et al. (2011). Clinical isolates of C. tertium, C. septicum, C. clostridiiforme and $C$. perfringens showed negative results using AdvanSure RT-PCR.

A total of 17 C. difficile isolates were recovered from 127 consecutive specimens in culture. Among them, 11 were toxigenic isolates $(8.7 \%$ prevalence); seven had the genotype $t c d A^{+} / t c d B^{+}$and four had the genotype $t c d A^{-} / t c d B^{+}$as determined by single gene specific PCR for the detection of $t c d A$ and $t c d B$ genes. All $\mathrm{TcdA}^{-} / \mathrm{TcdB}^{+}$ isolates shared an identical ribotype, 017. Binary toxinproducing $\left(\mathrm{TcdA}^{+} / \mathrm{TcdB}^{+} / \mathrm{CDT}^{+}\right)$strains were not detected in this study.

The AdvanSure RT-PCR experiments showed $t c d A^{+} /$ $t c d B^{+}$results in all seven specimens harbouring $C$. difficile with the $\mathrm{TcdA}^{+} / \mathrm{TcdB}^{+}$phenotype and $t c d A^{-} / t c d B^{+}$results in all four specimens harbouring C. difficile with the $\mathrm{TcdA}^{-}$/ $\mathrm{TcdB}^{+}$phenotype. VIDAS-CDAB showed positive results in seven specimens and false-negative results in four specimens harbouring $\mathrm{TcdA}^{+} / \mathrm{TcdB}^{+}$cells. One specimen with no data and one specimen showing equivocal results in VIDAS$\mathrm{CDAB}$ tests were excluded. Compared with the toxigenic $C$. difficile culture method, the sensitivity, specificity and positive and negative predictive values for AdvanSure RTPCR were $100 \%, 98.3 \%, 84.6 \%$ and $100 \%$, respectively, and those for VIDAS-CDAB were $63.6 \%, 100 \%, 100 \%$, and $96.6 \%$, respectively (Table 1 ). The results showed that AdvanSure RT-PCR offers sensitivity and specificity that is comparable to the reference method. The current study had a low sample size $(n=127)$; resulting in only 11 positive specimens. This was reflected especially by the positive predictive values which had large confidence intervals of 65$100 \%$.

EIA for the detection of toxins A and B are relatively quick but are known to have widely varying sensitivities (38$81.6 \%$ ) (Ticehurst et al., 2006; Eastwood et al., 2009; Alcalá et al., 2010). The VIDAS-CDAB test is a new ELFA that detects toxins $A$ and $B$. The sensitivity and specificity of the VIDAS-CDAB test were reported to be 89.8 and $96.7 \%$, by Eastwood et al. (2009), 65.3 and $93.8 \%$ by Shin et al. (2009) and 69.4 and $98.1 \%$ by Alcalá et al. (2010), respectively. In the current study, the sensitivity and specificity of the VIDAS-CDAB test were 63.9 and $100 \%$, respectively. These results were comparable to those from two later studies (Shin et al., 2009; Alcalá et al., 2010). The sensitivity of VIDAS-CDAB is too low to use as a standalone test; however, it has some advantages, including rapid turnaround time and ease of use, and could be used in a two-step testing system.

In Korea, C. difficile $\mathrm{TcdA}^{-} / \mathrm{TcdB}^{+}$strains have emerged recently (Kim et al., 2008, 2010). The prevalence of $\mathrm{TcdA}^{-}$/ $\mathrm{TcdB}^{+}$strains increased from $13.0 \%$ in 2002 to $27.1 \%$ in 2006 and reached $39.6 \%$ in 2004. In another Korean study in 2004 , the proportion of $\mathrm{TcdA}^{-} / \mathrm{TcdB}^{+}$strains was even higher: $45.7 \%$ of 81 isolates (Shin \& Kuak, 2006). Unlike other commercially available RT-PCR assays, which target $t c d B$ only or $t c d B$ and a single nucleotide deletion at position 117 in the $t c d C$ gene, used for the presumptive identification of PCR ribotype BI/NAP/027 (Huang et al., 2009; Eastwood et al., 2009), AdvanSure RT-PCR targets $t c d A$ and $t c d B$ genes, resulting in accurate differentiation between $\mathrm{TcdA}^{+} / \mathrm{TcdB}^{+}$and $\mathrm{TcdA}^{-} / \mathrm{TcdB}^{+}$isolates. This advantage makes the kit more useful in countries with high 
Table 1. Comparison of AdvanSure CD RT-PCR and VIDAS-CDAB methods to the toxigenic culture method for the detection of Clostridium difficile

PPV, Positive predictive value; NPV, negative predictive value.

\begin{tabular}{|c|c|c|c|c|c|c|c|}
\hline \multirow[t]{2}{*}{ Assay and Result } & \multicolumn{3}{|c|}{ Toxigenic culture } & \multicolumn{4}{|c|}{ Assay Performance (95\% confidence interval) } \\
\hline & $t c d A^{+} / t c d B^{+}$ & $t c d A^{-} / t c d B^{+}$ & $t c d A^{-} / t c d B^{-}$ & Sensitivity (\%) & Specificity (\%) & PPV (\%) & NPV (\%) \\
\hline AdvanSure RT-PCR & & & & 100 & $98.3(95.9-100)$ & $84.6(65.0-100)$ & 100 \\
\hline$t c d A^{+} / t c d B^{+}$ & 7 & 0 & 1 & & & & \\
\hline$t c d A^{-} / t c d B^{+}$ & 0 & 4 & 1 & & & & \\
\hline$t c d A^{-} / t c d B^{-}$ & 0 & 0 & 114 & & & & \\
\hline Total $(n=127)$ & 7 & 4 & 116 & & & & \\
\hline VIDAS-CDAB & & & & $63.6(35.2-92.1)$ & 100 & 100 & $96.6(93.3-99.9)$ \\
\hline Positive & 3 & 4 & 0 & & & & \\
\hline Negative & 4 & 0 & 114 & & & & \\
\hline Total $(n=125) \dagger$ & 7 & 4 & 114 & & & & \\
\hline
\end{tabular}

${ }^{\star}$ Results represent number of isolates testing positive or negative for $t c d A$ and/or $t c d B$ genes.

$\dagger$ Two specimens were excluded, one of them due to an equivocal result and the other an unavailable result.

prevalence rates of $C$. difficile with the phenotype $\mathrm{TcdA}^{-} /$ $\mathrm{TcdB}^{+}$. Another possible advantage of the AdvanSure RTPCR system is the ability to monitor the emergence of new genotypes, such as the appearance of $t c d A^{+} / t c d B^{-}$ (Rupnik, 2008). Furthermore, the turnaround time of the AdvanSure RT-PCR was very short $(\sim 3 \mathrm{~h})$ compared to the toxigenic culture method $(48-72 \mathrm{~h})$.

In conclusion, AdvanSure RT-PCR may provide an optimal laboratory method for the diagnosis of CDI with rapid turnaround time and reliable diagnostic accuracy.

\section{ACKNOWLEDGEMENTS}

This study was supported by a research grant from LG Life Sciences, Daejeon, Korea and by a grant from the National Research Foundation of Korea, funded by the Korean Government (20100017322).

\section{REFERENCES}

Alcalá, L., Marín, M., Madrid, M., Dominguez-Garcia, E., Catalán, P., Peláez, M. T., Sánchez-Somolinos, M. \& Bouza, E. (2010). Comparison of ImmunoCard Toxins $A \& B$ and the new semiautomated Vidas Clostridium difficile Toxin $\mathrm{A} \& \mathrm{~B}$ tests for diagnosis of $C$. difficile infection. J Clin Microbiol 48, 1014-1015.

Barbut, F., Monot, M., Rousseau, A., Cavelot, S., Simon, T., Burghoffer, B., Lalande, V., Tankovic, J., Petit, J. C. \& other authors (2011). Rapid diagnosis of Clostridium difficile infection by multiplex real-time PCR. Eur J Clin Microbiol Infect Dis 30, 1279-1285.

Bartlett, J. G. (2002). Clostridium difficile-associated enteric disease. Curr Infect Dis Rep 4, 477-483.

Cohen, S. H., Gerding, D. N., Johnson, S., Kelly, C. P., Loo, V. G., McDonald, L. C., Pepin, J., Wilcox, M. H., Society for Healthcare Epidemiology of America \& Infectious Diseases Society of America (2010). Clinical practice guidelines for Clostridium difficile infection in adults: 2010 update by the Society for Healthcare epidemiology of America (SHEA) and the Infectious Diseases Society of America (IDSA). Infect Control Hosp Epidemiol 31, 431455.

Crobach, M. J., Dekkers, O. M., Wilcox, M. H. \& Kuijper, E. J. (2009). European Society of Clinical Microbiology and Infectious Diseases (ESCMID): data review and recommendations for diagnosing Clostridium difficile-infection (CDI). Clin Microbiol Infect 15, 10531066.

de Boer, R. F., Wijma, J. J., Schuurman, T., Moedt, J., Dijk-Alberts, B. G., Ott, A., Kooistra-Smid, A. M. \& van Duynhoven, Y. T. (2010). Evaluation of a rapid molecular screening approach for the detection of toxigenic Clostridium difficile in general and subsequent identification of the $t c d C \Delta 117$ mutation in human stools. J Microbiol Methods 83, 59-65.

Eastwood, K., Else, P., Charlett, A. \& Wilcox, M. (2009). Comparison of nine commercially available Clostridium difficile toxin detection assays, a real-time PCR assay for $C$. difficile $t c d B$, and a glutamate dehydrogenase detection assay to cytotoxin testing and cytotoxigenic culture methods. J Clin Microbiol 47, 3211-3217.

Huang, H., Weintraub, A., Fang, H. \& Nord, C. E. (2009). Comparison of a commercial multiplex real-time PCR to the cell cytotoxicity neutralization assay for diagnosis of Clostridium difficile infections. J Clin Microbiol 47, 3729-3731.

Kim, H., Riley, T. V., Kim, M., Kim, C. K., Yong, D., Lee, K., Chong, Y. \& Park, J. W. (2008). Increasing prevalence of toxin A-negative, toxin Bpositive isolates of Clostridium difficile in Korea: impact on laboratory diagnosis. J Clin Microbiol 46, 1116-1117.

Kim, H., Jeong, S. H., Roh, K. H., Hong, S. G., Kim, J. W., Shin, M. G., Kim, M. N., Shin, H. B., Uh, Y. \& other authors (2010). Investigation of toxin gene diversity, molecular epidemiology, and antimicrobial resistance of Clostridium difficile isolated from 12 hospitals in South Korea. Korean J Lab Med 30, 491-497.

Knetsch, C. W., Bakker, D., de Boer, R. F., Sanders, I., Hofs, S., Kooistra-Smid, A. M., Corver, J., Eastwood, K., Wilcox, M. H. \& Kuijper, E. J. (2011). Comparison of real-time PCR techniques to cytotoxigenic culture methods for diagnosing Clostridium difficile infection. J Clin Microbiol 49, 227-231.

Kuijper, E. J., Barbut, F., Brazier, J. S., Kleinkauf, N., Eckmanns, T., Lambert, M. L., Drudy, D., Fitzpatrick, F., Wiuff, C. \& other authors 
(2008). Update of Clostridium difficile infection due to PCR ribotype 027 in Europe, 2008. Euro Surveill 13, 18942.

McDonald, L. C., Killgore, G. E., Thompson, A., Owens, R. C., Jr, Kazakova, S. V., Sambol, S. P., Johnson, S. \& Gerding, D. N. (2005). An epidemic, toxin gene-variant strain of Clostridium difficile. $N$ Engl J Med 353, 2433-2441.

Rupnik, M. (2008). Heterogeneity of large clostridial toxins: importance of Clostridium difficile toxinotypes. FEMS Microbiol Rev 32, 541-555.

Shin, B. M. \& Kuak, E. Y. (2006). [Characterization of a toxin Anegative, toxin B-positive variant strain of Clostridium difficile]. Korean J Lab Med 26, 27-31 (in Korean with English abstract).

Shin, B. M., Lee, E. J., Kuak, E. Y. \& Yoo, S. J. (2009). Comparison of VIDAS CDAB and CDA immunoassay for the detection of Clostridium difficile in a $t c d A^{-} t c d B^{+}$C. difficile prevalent area. Anaerobe 15, 266-269.
Spigaglia, P. \& Mastrantonio, P. (2004). Comparative analysis of Clostridium difficile clinical isolates belonging to different genetic lineages and time periods. J Med Microbiol 53, 1129-1136.

Stamper, P. D., Alcabasa, R., Aird, D., Babiker, W., Wehrlin, J., Ikpeama, I. \& Carroll, K. C. (2009). Comparison of a commercial realtime PCR assay for $t c d B$ detection to a cell culture cytotoxicity assay and toxigenic culture for direct detection of toxin-producing Clostridium difficile in clinical samples. J Clin Microbiol 47, 373-378.

Terhes, G., Urbán, E., Sóki, J., Hamid, K. A. \& Nagy, E. (2004). Community-acquired Clostridium difficile diarrhea caused by binary toxin, toxin A, and toxin B gene-positive isolates in Hungary. J Clin Microbiol 42, 4316-4318.

Ticehurst, J. R., Aird, D. Z., Dam, L. M., Borek, A. P., Hargrove, J. T. \& Carroll, K. C. (2006). Effective detection of toxigenic Clostridium difficile by a two-step algorithm including tests for antigen and cytotoxin. J Clin Microbiol 44, 1145-1149. 